\title{
Continuous formation of liturgy through social cognition
}

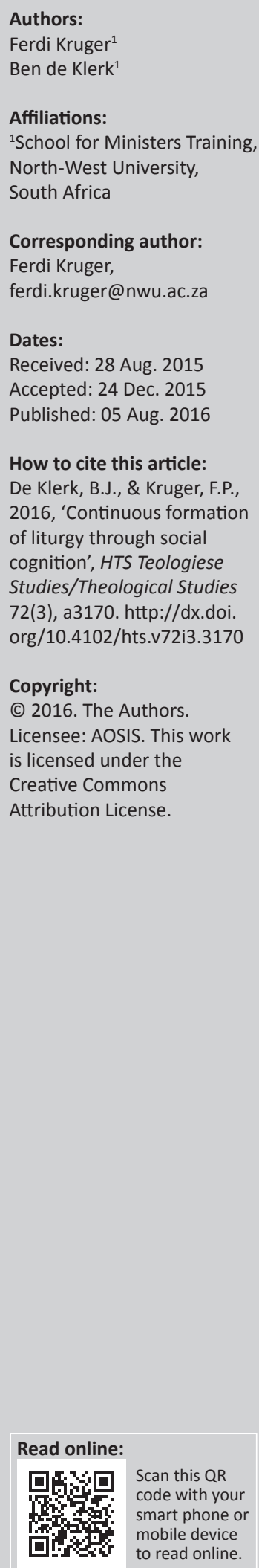

This article researches two focal points, namely liturgical formation and the influence that social cognition has on liturgical formation. Within a South African context it is evident that Western liturgical traditions encounter African traditions and vice versa. This encounter is challenging because it creates new questions. The process of enculturation is prominent in recent research. The article refers to the process of social cognition as the manner in which people observe each other and try to make sense of other cultures and the people of those cultures. People's cognition can be wrong, leading to distortions. The main research question for this investigation emanates from this possibility, namely: How does social cognition influence the process of liturgical formation? The authors first of all offer a descriptiveempirical vantage point to investigate this matter. Two local congregations were visited. The authors reflect on their own cognition, but also examine the cognition of the leaders through interviews. Based on the findings of this endeavour, normative perspectives are formulated from Acts 17:16-35 to highlight the role of cognition in liturgical formation. Throughout, the article includes consideration of the hermeneutic interaction between the various elements of this research and provides hermeneutic guidelines.

\section{Introduction}

Liturgy is ever-changing and has the potential to change people and cultures. Moeller (1998:16) aptly comments that '[w]orship is our reality as Christians, the whole out of which and in which we come to know who we are'. Believers become participants in the service of worship through their liturgy, a liturgy that should enrich the liturgy of life (De Klerk 2007:29). People create liturgy, but liturgy also transforms people (Barnard \& Vos 2001:21). In the Newsletter of the Societas Liturgica, Geldhof, Larson-Miller and Stuflesser (2014:4) indicate that liturgy is in a way itself a teaching or initiating reality which itself forms, re-forms or transforms. An essential dimension of reflections on this field is the role of the self-understanding of the worshipping community, an aspect that has to do with social cognition. ${ }^{1}$ The influence of social cognition on liturgy and liturgical formation in a changing world within changing contexts means that even liturgy can't function unchanged (Clasen 2008:37).

The relationship between liturgy and culture is therefore a prominent item on the agenda of churches worldwide. Heitink (2007:28-30) indicated at the beginning of a new millennium that worship is becoming more complex and more diverse because of a new focus on the church as a worldwide community of believers. People from different ethnic and cultural backgrounds constantly seek a better understanding of people from other cultures, but the problem is that they have to make inferences based on limited information about those cultures (Fiske 2004:133). Conder (2006:18) further indicates that the church worldwide is also experiencing somewhat of a transition into a new cultural era. The entry into this cultural era has implications and offers opportunities and challenges. Moynagh (2012:352) highlights certain responses of churches in this transition and underlines the tendency of some churches to expect conformity to prescribed liturgies and liturgical orders.

Moynagh (2012:353) distinguishes four possible responses by churches regarding the transition into a new cultural era, namely:

- inherited worship that relies on fixed patterns for worship and fixed liturgies

- emerging worship that seeks engagement with postmodern culturecontextual worship or liturgy that puts the emphasis on indigenising worship. According to this approach, the liturgy for worship will look different in different contexts

- blended liturgy for services of worship that bring context and the tradition of worship together - the authors of this article subscribe to this last option.

1.Social cognition refers to the process during which people think about and make sense of other people, situations and themselves. 
The information above shows that liturgy formation is not a fixed reality (cf. Societas Liturgica 2014:5). Having changed and evolved over the course of history just as liturgy itself did, liturgical formation adapts to cultural changes. These changes include: different ways of transmission and teaching in various cultures, different conceptions of the life of the church, and the different types of addressee: the faithful, the ordained, those in formation, academic teachers, and students. Participants in a service of worship also join a social community so that they can relate to one another (Immink 2014:7). Church members are part of a diverse society, socially, culturally and religiously. Culture is an interweaving of what people believe, what they think and how they work through possible relationships (Best 2003:173). Local congregations have become diverse and this trend has tended to lead to tensions about liturgical styles (Immink 2014:9). Liturgy should not be so foreign that it does not communicate with its cultural environment, but surely it should not be so local-contemporary that it robs the gospel of its transforming power (De Klerk 2014:49).

People rely on social cognition as a process to make sense of other people, of themselves and also of the social situation (Eysenck \& Keane 2010:585). People often tend to take shortcuts in the process of cognition and therefore cognition could go terribly wrong. When people from different cultures meet one another, cultural evaluation can take place at various levels, namely cognitive, affective (emotional) and evaluative. Certain dangers are evident here, namely misunderstanding other people, feeling superior towards other cultures and the condemnation of others. In a South African context churches are often faced with the challenge of Western liturgical traditions and African liturgical traditions encountering each other in a new political dispensation. Since 1994 there has been a growing sensitivity towards the differences between cultures. The question therefore arises why believers from different cultures are struggling to comprehend the richness of their own liturgical traditions. In which manner can believers contribute to the formation of liturgy so as to enrich liturgy in order to enhance society?

This article highlights only one aspect that can be considered as a starting point in this discussion, namely the role of social cognition. Research on this topic is relevant because it has to do with the mental processes involved in acquiring knowledge (Weiten \& Weiten 1992:270). In the formation of liturgy it is insightful to take note of the fact that people from different cultures observe one another and try their best to understand people from different cultures. However, people's observations or impressions of those from different cultures can be either correct or incorrect (Fiske 2004:121). People tend to gather data through contact with individuals from different cultures and this gathering of data also determines the reactions towards one another (Louw \& Edwards 1998:548). Cognition therefore has a direct influence on people's attitudes towards one another.

Subsequently, the main research question for this investigation is then: How does social cognition influence the process of liturgical formation? In other words: 'In what way can social cognition positively influence a convergence liturgy?'

Most scholars within the field of Practical Theology use a hermeneutic-communicative approach. It is this hermeneutic-communicative dimension that opens the way to understanding liturgy as a way of meeting (Barnard \& Vos 2001:18). The methodological insights of Osmer guide the four phases of our research. Osmer (2008:23) proposes a model of practical theological interpretation comprising four tasks:

1. The descriptive-empirical task asks: 'What is going on?'

2. The interpretive task asks: 'Why is it going on?'

3. The normative task asks: 'What ought to be going on?'

4. The pragmatic task asks: 'How might we respond?'

\section{Descriptive-empirical research on the interaction between liturgical formation and context and/ orculture Descriptive analysis of the field of investigation}

Osmer (2008:34) explains this phase in practical theological research as a matter of attending to what is going on in the lives of individuals, families and congregations. He refers to such attending as 'priestly listening'. The two pivotal aspects in our field of investigation are continuous liturgical formation and social cognition.

\section{Continuous liturgical formation}

Formation through participation: It has long been appreciated that although we shape our worship, the way we worship also shapes us. Fowler (1991:181) states: 'With liturgy we deal with kinaesthetic (the sensory experience) of faith'. For Fowler, liturgy as the sensory experience of faith focuses on the imaginable character of worship and its power to suggest, form and evoke the images that represent our convictional knowing (1991:181). The rituals and ceremonials of a worshipping community (church) are the most influential in the shaping of faith, character and consciousness (Westerhoff 1987:514). Liturgical practices give expression to the particular beliefs, values and feelings of a specific faith community and in that way to their identity (Anderson 1997:361).

The aim of achieving full, conscious and active participation in worship has been a universal cry of liturgical scholars, writers, planners and leaders of worship (Burton-Edwards 2013:41). Continuous liturgical formation should involve liturgical activities, because by participating in liturgical activities the mind, emotions and body of members work together as a holistic entity, as the Body of Christ (cf. Smith 2009:40). What participants do during a service of worship is of greater importance than what the leader of the worship does and says. 'We do not gather in order for each individual to have some kind of inner experience or feeling', argue Strawn and Brown, 'but for each whole person and the gathered 
Church to be formed through the context of worship' (2013:12). Liturgical patterns where the leaders as performers do most of the activities and the congregants become passive audiences stand in contrast to congregants being incorporated in practices so that they are not only participants but the performers (Anderson 1997:356). The continuous formation of liturgy is not a discussion about the different elements in the service of worship, but an enactment of the knowledge that God is present (Ostdiek 1986:9).

Formation through interaction: Liturgy is not fixed, with certain immutable qualities that originated during a certain stage of history, nor is it a blank slate. In the formation process there is a combination of a certain predisposition and the experience-based emergence of liturgical capacities, identity and character through a continuous history of situational and social interactions (Strawn \& Brown 2013:5). In the view of Anderson (1997:355), 'The history of Christian liturgy represents an ebb and flow between improvisation and fixing texts, between innovation and institutionalisation'. Continuous formation takes place through interaction with culture and other liturgies and through processes such as imitation, emotional attunement and interpersonal attachments (Strawn \& Brown 2013:6-7). As part of this process, imitation is needed for the development of identity and spiritual formation. Interpersonal contact between participants from one liturgical tradition and believers from other traditions can bring about change and growth in one's own liturgical practice. Such contact has the power to create empathy for the traditions of others.

Liturgy is continuously formed through interaction, sharing, communion, corporate prayer, common stories and the connectedness of living together (Strawn \& Brown 2013:12). The intensity or lack of intensity in the ongoing daily worship life of people - the so-called liturgy of everyday life - influences the liturgy of the congregation in either a positive or a negative way. In the interaction of people in liturgy language plays a major role.

Liturgical language plays a crucial interacting role in liturgy in general and it can also contribute to its further formation. The language of the present culture and the cultures of people living in the surroundings therefore have an influence on the further formation of liturgy. The language used in the liturgies of other traditions, like the language of their songs, preaching and prayers, may become part of the liturgy through the influence that it has on participants in that liturgy. Language opens possibilities of further formation because it creates a space for imagination and new possibilities (Strawn \& Brown 2013:8-9). Imagination is a creative aspect of the continuous formation of liturgy (Gallet 2000:114). The language of music, together with silence, is one of the most profound languages in the continuous formation of liturgy. It is the same with the ritual language of dying and rising in baptism, the reception of bread and wine, and body language in prayers and songs (Anderson 1997:357).
Formation through balance between action and knowing, tradition and enculturation: A misunderstanding of continuous liturgical formation is that it can happen only through rational activities. Strawn and Brown (2013:3) indicate that 'even Christian worship has been undergirded by the idea that humans are "thinking beings"'. They argue (2013:3) that 'the consequence of this anthropology is that humans became walking heads, disembodied and disconnected from what they actually do in the world and disconnected from the other bodies around them'. Continuous liturgical formation will then take place only when the congregants are continuously taught about their creeds and formulas and the meaning of every element in the service of worship. Thinking and teaching are essential, but is that the only way that liturgy is formed? There is a reciprocal relationship between action and knowing (Anderson 1997:352).

Continuous formation is not only what we think or believe, but is established by kinds of social and physical interaction with the world that we engage through liturgies. The social interactions we experience as a church, including the ritual interactions we enact in worship, are essential aspects of liturgical formation (Strawn \& Brown 2013:11). In some denominations the focus is mainly on the doctrinal side of liturgical practices, but such a focus neglects the bodily aspect. Others may inculcate bodily practices but offer little direct doctrinal interpretation to accompany them (BurtonEdwards 2013:49). Culture and the ethos of the worshipping group may be the reason for the focus on either doctrinal issues or bodily expressions. In continuous liturgical formation, openness to the differences may play a transparent role in, for example, the expression of joy and sorrow and bodily movements during liturgical participation.

The changes in liturgical formation form a balance between continuous preservation of the integrity of a group's own liturgy and allowing for growth by social cognition, between tradition and enculturation. Openness to experience allows for flexibility in the formation of identity and practices as well as the assimilation of cultural modes of thought and behaviour (Strawn \& Brown 201:310). In a world full of heresies and cultural changes, it is necessary to arrive at the formulation of liturgical principles in decisions and formulas. Once texts and formulas became fixed, 'they tended to be treated like museum pieces that had to be protected and preserved at all costs' (Anderson 1997:355). In the whole process of the continuous formation of liturgy, wisdom to judge and to discern what to adopt and what not are of crucial importance.

\section{Interpretative perspectives on social cognition from the viewpoint of social psychology}

\section{Cognition as a process through which people try to make sense of other people}

The relation between cognition and human emotions has received attention in recent years within the focus area of cognitive psychology (Eysenck \& Keane 2010:571). Weiten and Weiten (1992:270) wrote about the cognitive revolution 
psychology has experienced. In their opinion, cognition refers to the mental processes involved in acquiring knowledge: cognition has to do with thinking. Baron and Byrne (1994:108) in turn highlight the need for people to think about and increase their understanding of people and events. They also indicate the fact that when people are experiencing positive feelings (affect), difficult tasks seem easier to deal with. On the contrary, people tend to cope with tasks and problems with great difficulty when they are experiencing negative feelings (Baron \& Byrne 1994:115). People's emotional experience is influenced not only by their concrete situation, but also by their cognitive observation, appraisal or interpretation of that particular situation (Eysenck \& Keane 2010:571-572).

Fiske (2004:123) offers a different angle on this topic by indicating that social cognition constitutes the process through which people think about and make sense of other people, themselves and their social situation. This view focuses especially on how people form impressions of one another's personalities, emotions, roles, cultures and identities (Fiske 2004:122). People think about other people in order to interact with them (Louw \& Louw 2007:24). Social cognition is the process through which people try to make sense of one another. It happens in milliseconds, but it is easy in this process to commit serious errors (Fiske 2004:121). Wood and Wood (1999:228) also highlight the idea that cognition has to do with a certain mental process involved in acquiring, storing, retrieving and using knowledge. The functioning of perceptions is a specific process or manner of social cognition. Woolfolk (2007:251) did research on the functioning of perceptions within the framework of information processing in memory and concluded that a perception has to do with the process of detecting a stimulus and assigning meaning to it. It is a way of interpreting sensory information (Woolfolk 2007:251). Schwartz and De la Rey (2004:355) indicate that people want to organise things they observe and therefore they always tend to see things and people against a certain background.

Eysenck and Keane (2010:35) refer to the role of everyday visual perception, which allows people to see and observe the individuals with whom they are interacting. People rely on visual perception in order to be accurate in ensuring their own safety. According to Eysenck and Keane (2010:36), the functioning of visual perceptions has to do with the functioning of people's senses (people see, they hear, they taste, they feel). Louw and Edwards (1998:149) rightfully indicate that people's observation of others is not just a biological matter: all people have something that can be called a 'perceptual disposition'. Their observations of things and other people are influenced by a certain kind of framework (an orientation framework).

\section{Cognitive distortions endanger perspective-making}

The danger also exists that one person's observation of other people could be wrong (Fiske 2004:121). The role of social cognition is really prominent because of the fact that people continuously tend to form opinions about others and consider whether other people make sense to them (Baron \& Byrne 1994:108). It is a fact that thinking about other individuals determines social interaction (Fiske 2004:123). When social cognition results from social interaction between people, they gather data about other people. Fiske (2004:123-127) highlights the following aspects in this regard:

- People often try to cut corners when attempting to make sense of other people; this is called the function of cognitive misers. It entails people making use of dimensions or habitual categories instead of thoroughly thinking about others.

- People's social cognition should be accurate enough to guide them through their everyday interactions. But the other side of the coin is also true, namely that people's cognitions should also be flexible enough to change with changing contexts and circumstances.

Louw and Edwards (1998:548-549) emphasised the functioning of cognitive distortions:

- Over-generalisation. In this kind of distortion people tend to think of other people in a generic way. In the case of cultural and ecclesiastical differences people often think that other people are their enemies or opponents.

- Arbitrary conclusions. People tend to draw conclusions without the full picture of knowledge about and insight into other people's lives.

- Selective abstraction. People tend to focus on a small part of reality while they ignore other facts.

- All-or-nothing thinking. People tend to think that others either make sense to them or they do not.

What is the reason for the functioning and existence of social cognitive distortions? One of the major reasons is misguided schemes (Barker \& Angepoulo 2010:67; Fiske 2004:143). The problem with these kinds of scheme is that they were created during the early stages of childhood. These automatic thoughts about other people could be so wrong that they may have a negative impact on the social interactions between people and on individuals or groups from different cultures (Barker \& Angepoulo 2010:68). The chain effect of cognitive distortions is even more concerning when one considers the fact that they also influence people's ability to make or create perspective (Louw \& Louw 2007:305). The ability to make or create perspective has to do with the ability to view life from the perspective of others. In the research about the formation of liturgy this is a major aspect that liturgical research has to take into consideration. In the formation of liturgy it will become increasingly valuable from a South African perspective that different cultures adopt new perspectives and learn to view liturgical formation from the viewpoint of other cultures.

\section{Qualitative-empirical research on social cognition and the continuous formation of liturgy Data-gathering method}

In this part of the research the authors followed a qualitative approach to get a picture of what is going on. Respondents from 
various cultural backgrounds in the Potchefstroom area of South Africa were selected. The chosen sample consists of people who are acquainted with the role of the formation of liturgy in a South African context. De Vos et al. (2011:435-436) indicate that the use of open questions and a semi-structured questionnaire could be very helpful during interviews because it promotes a flexible discourse. The authors decided to formulate certain questions regarding the importance of the continuous formation of liturgy, the view of different cultures towards liturgy and the role of people who want to make sense of other people because of what they see and experience (social cognition) beforehand.

The authors processed the data ${ }^{2}$ gained from the interviews by using the inductive method and putting the data into smaller categories. The investigation was a phenomenological study in which we sought 'the essence of an activity' of the formation of liturgy. The experience of social cognition for a group of people was also investigated (cf. Osmer 2008:52). The authors gathered data on the lived experience of participants and then analysed the data in order to grasp the essence of this matter (Osmer 2008:53).

In this research the authors used the method of structured and focused interviews. The interviewer didn't give direction to the interviewee with regard to the types of answer provided. The interview was structured in such a manner that the interviewee's attention was drawn to the topic of the research in order to gain information on their views of it.

\section{Data collection}

The following respondents were selected for interviews, namely the ministers in a Reformed congregation serving a Sesotho-speaking culture (participant 1) and also a multicultured Roman Catholic congregation ${ }^{3}$ (participant 2). The authors visited the services of worship of the local congregations and made appointments with the ministers to interview them after the services. ${ }^{4}$ The reason why these congregations were selected was primarily because they are known for their efforts in forming liturgies between various cultures.

All the interviews were recorded by means of thorough minutetaking. The authors intended to make their own cognitions by attending the worship services of the congregations. Both authors independently wrote down their own cognitions and made them available to each other. The ministers were

2. The results of the interviews are available and can be viewed in the presence of the authors.

3. The context of the liturgy of the Roman Catholic Church in Potchefstroom: it is a Roman Catholic Church of mixed cultures, including SeTswana-, Afrikaans-, Portuguese- and isiXhosa-speaking members. The language used is British/SA English and American English and the accompaniment instruments are keyboards, guitar and accordion. It is not the typical praise and worship rhyme.

4. The context of the liturgy of the Reformed Church in Venterskroon: it is a The context church of mainly SeSotho-speaking memb. The liturgy follows Reformed pattern of prayer, scripture reading, preaching and songs. The songs Reformed patter of are taken from the Lifela hymn book (a more Lutheran type of hymn book) and the accompaniment instruments are drums and bells. The rhyme is typical of the African culture. interviewed according to the set of questions reproduced in this paper. Afterwards the authors analysed and interpreted the content on the basis of the conceptualisation of the results of this empirical research. The interviews were constructed on the basis of the following questions that asked for the interviewee's opinion, namely:

- What do you think the aim of continuous liturgical formation is?

- How can the congregation participate in continuous liturgical formation?

- How would you describe the interaction of your liturgy with and openness of your liturgy to culture?

- How would you describe the interaction of your liturgy with and openness of your liturgy to other liturgies?

- What do you think the influence of expression is in acts of worship on continuous liturgical formation?

- How would you keep the balance between doctrinal convictions and the assimilation of cultural tendencies?

- How do you think the joy in your liturgy can influence the traditional Western-Reformed liturgy?

- How do you think the bodily expression experience in your liturgy can influence the traditional WesternReformed liturgy?

- How do you think the different cultural contexts can positively influence the other's formation of their liturgy?

\section{Data analysis and interpretation}

In the following section the authors are providing an analysis of the participants understanding on how social cognition is important within the process of continuous liturgical formation (Table 1; Figure 1).

Interpretation of data from the interviews and the cognition of the authors: The following aspects stood out after the completion of both interviews:

- Before implementing liturgical formation in a multicultural environment it is pivotal to comprehend the deepest need and the reason for it. When cultures meet each other, it is imperative to be true to liturgical principles without ignoring the ability to adapt to new situations. The correct and responsible cognition of cultures and people is needed and this fact requires suitable study.

- Liturgical formation stimulates the recognition of God's presence during services of worship.

- Liturgy from the viewpoint of the liturgist and from that of people who are communicating aspects of liturgy during the service of worship should be prepared well in order to help people make sense of it. Liturgical formation asks for thorough consideration and good preparation. People form a cognition during the service of worship.

- Culture plays a crucial role in people's lives. Liturgists are responsible for helping participants make liturgy their own. Culture performs the function of dressing liturgy. 
TABLE 1: Participants' understanding on how social cognition is important.

\section{Question}

hat do you think the aim of continuous liturgical

formation is?

How can the congregation participate in continuous liturgical formation?

Analysis of participants

1

It will lead to the realisation of the daily presence of God and preserve the congregation from formalism. Liturgical formation stimulates the recognition of this presence. Therefore liturgy should be dynamic to help participants in liturgy to realise something about this holy sphere and/or space of God's presence.

Culture plays a pivotal role in people's lives. Liturgists have the role to help participants to make liturgy their own. The liturgy brings to the foreground the dialogue with God and each other. Participants in liturgy become with God and each other. Participants in liturgy become People should be able to experience the link to liturgy and therefore it should not be totally strange to them.

How would you describe the interaction and openness of your liturgy to culture?

Culture has the function to dress liturgy. The liturgical principles towards daily life should be embraced through the cultural clothing of liturgy. In our congregation there are people from different cultural backgrounds and cultural customs (P1).

How would you describe the interaction and openness of your liturgy to other liturgies?

In the beginning it was difficult to expose the congregation to another kind of liturgy. In recent times the congregation actually welcomed different cultures. The concept of 'you are welcome' is evident. The congregation has a critical openness towards liturgies of other denominations. It is necessary for them to listen and hear what other cultures do.

Expression is part of being and how people are. It is more a case of becoming what you are. The congregation express themselves during the liturgy, but it is organic and spontaneous.

of worship on continuous liturgical formation?

How do you think the joy in your liturgy can influence the traditional Western-Reformed liturgy?

It is a case of the right attitude towards other cultures and a willingness to be open to learning. The attitude of openness to learn from other cultures and also from their customs is necessary. It is a case of 'you are welcome here' and also of 'feel welcome here'.

Bodily expression that flows from pure joy is essential in our culture. Different cultures should have an openness to this. Do what you are familiar with without neglectin the liturgical principles.

There are different cultures in God's Kingdom. There should be an earnest attempt to come to an understanding of each other. When cultures are coming together, there should be enrichment and not any attempt to conquer the other culture to form another culture. Accommodation of each other is needed. Be there in order to understand each other.
How do you think the different cultural contexts can

positive
liturgy?
It will lead to a better relationship with God. Liturgy is able to bring people to truly meet God and to pray wholeheartedly Liturgy enables people to communicate better with God in daily life. Liturgy should inter alia lead to prayer in a certain sense of the word.

Participants in worship services have to learn to attend services on a regular basis to be exposed to liturgy. Liturgy services on a regular basis to be exposed to liturgy. Liturgy who is doing something during the worship service should be thoroughly equipped and they have to prepare themselves for their responsibility in Scripture reading (proclaiming), prayer, music. Liturgists help participants make liturgy their own and to achieve this the liturgist has
to set a good example of sensitivity. People who are participating will be able to listen and then to act.

Culture is playing a very prominent role in people's lives. However, no culture should be in a position to dominate
another one. There should be sensitivity for people of other another one. There should be sensitivity for people of othe
cultures. Enculturation has its own limits. Liturgists and cultures. Enculturation has its own limits. Liturgists and
local congregations should develop the ability of discretion

Sensitivity is needed. Although the congregation has not been exposed to other kinds of liturgy, they are sensitive to them (according to the minister). Powerful preaching of the Word is central to the formation of liturgy in this

congregation with its multi-cultural composition. Preaching the Word of God and especially preaching with good exposition and contextualised application helps people to focus on the fact that the main thing must stay the main thing in liturgy. The main thing is to help people to meet God and therefore the Word of God must receive a central place. The gathering of people around the Bible (Bible study groups) to cultivate a hunger and thirst for God's Word is necessary.

Worship is also something that has to be experienced inside every participant. Real worshipping will lead to real change in people's lives. Therefore bodily expression is something that flows in an organic manner out of your heart: standing kneeling, singing and praying. It should not be artificial, but it has to convey the message of the liturgy. Anyone is free to act as they want.

The message of the Reformation (Calvin, Luther and others) can be implemented in practice, taking its essence to the outer limits. There is also room for experiencing the acts of faith (charismata). Rituals and symbols, for example, have their own place and importance. Liturgical freedom is freedom within boundaries. Worship services with a good structure and good leadership are needed to achieve that. Structure and good leadership are need the Worship services will deviate from the
conducted in an uncontrolled manner.

Bodily experience is very expressive. It gives expression to the message of the liturgy and contributes to the dialogue character of the worship service. Nobody has the ultimate freedom to go overboard (according to the minister).

Before going the route of enculturation, it is necessary to do a good study of the outlines of that culture. Have respect for all cultures, but take the good and leave the bad aspects of cultures. Influence occurs through face-to-face discussions and also via re-evaluation.
The local congregation has a critical openness towards other liturgies. It is essential for them to listen to and hear what other cultures do. The role of good communication in correcting distortions in cognitions can never be underestimated.

- Everybody should realise the difference between principles and customs. The cultural heritage of drums, bells and cushion-hitting is clearly strange to other cultures, but it is not necessarily wrong. It became clear that customs and music contribute towards the dedicated manner in which people feel they are meeting God and each other. Music styles and music instruments could also be functional in promoting liturgical formation.

- In order to address the issue of (continuous) liturgical formation it is essential that people from different cultures are exposed to one another.
- The attitude of openness to learning from other cultures and from their customs is enriching. It is a case of 'you are welcome here' and also 'feel welcome here'.

- When cultures come together, enrichment should be evident instead of attempts to conquer the other culture to form a different culture.

- Powerful and contextualised preaching of the Word of God contributes to a good assimilation of cultures. It prevents people from selfishness in the encounters between cultures.

- Services of worship should make sense to participants so that they can participate in daily life.

- The value of rituals and symbols could never be underestimated when cultures come together. Rituals and symbols contribute to continuous liturgical formation. 
Author A's and B's cognition after attending the service of worship at congregation 1: Both authors agreed on their cognition of the following aspects:

- The minister and the elders and deacons tried their best to provide us with their hymn books so that we could sing together in their mother tongue.

- The minister made use of an interpreter to help the visitors understand what the content of his sermon was.

- The liturgist didn't dictate the liturgy. He invited participation.

- The preaching of the Word was ethically oriented. The two authors of this article

- The preaching of the Word was ethically oriented. The two authors of this article
were invited to participate in liturgy through prayer and the sending-away blessing. - Our cognition of the liturgical acts during the worship service was that the worship service made sense and was easy to understand.
Author A's and B's cognition after attending the service of worship at congregation 2: Both authors agreed on their cognition of the following aspects:

- The rituals and symbols are very prominent. Each movement and gesture has a symbolic meaning and it seems as if people understood this very well. The liturgist symbolic meaning and it seems as if people understood this very well. The liturgist were doing certain things in a certain manner.

- Both authors experienced the cognition of feeling welcome at the worship service.

- Both authors experienced the cognition of feeling welcome at the worship service.

song, prayers and as proclaimers was outstanding.
Everything during the worship service contributed to the fact that a dedicated

atmosphere was making it possible to meet God and other people.

- The liturgist invited participation and did not dictate the liturgy, but still managed the events in a proper manner.

- Scripture reading and preaching gave the impression of good preparation.

- Bodily expression was organic and gave the opportunity to all cultures to

experience the worship service in a proper manner.

- The liturgy and preaching of the Word were in congruence with the common

culture that every participant could understand, namely the English culture (cf. footnote 3).

FIGURE 1: Authors' cognitions after attending services of worship.

- Participation in the liturgy is helpful to people's understanding of the value of the liturgy and services of worship.

In liturgical formation and especially where cultures encounter each other it is obvious that a common language must be used and that room must be made for other languages.

- Bodily expression is functional for certain people. Participants in the liturgy should feel free to express themselves in a way with which they feel comfortable.

\section{Ethical considerations and declaration}

The authors declare the following:

- There was no exclusion of interviewees on the grounds of sex, age, disability, education, religious beliefs, pregnancy, marital status, social origin or language.

- The authors also declare that there was no fabrication of data, falsification, manipulation of results or plagiarism.

- There is little risk involved for participants in this study and the benefits of this study for the broader society in South Africa overshadow the possible low risk.

- The authors made sure that this study does not polarise different denominations.

- Both authors have previous experience in conducting interviews.

\section{Normative perspectives on the formation of the liturgy}

The normative task asks: What ought to be going on? It seeks to discern God's will for present realities. Osmer (2008:61) refers to this task as 'prophetic discernment'. This subsection deals with questions such as: What was the role of the Scriptures in liturgical formation in Acts 17:16-35 and what could it be in the present context? Which approaches to the Word of God are helpful to give shape to liturgical formation? The following perspectives could be derived from the normative investigation of Acts 17:16-35. Many more perspectives could be derived from Acts, but this discussion focuses on this passage only. Insight into this passage can be helpful in identifying indicators for the continuous formation of a liturgy through social cognition.

\section{Perspectives on liturgy conveying a message to all cultures: Acts 17: 16-35}

Larkin (2006:252) highlights the prominence of this particular passage by indicating that this sermon by Paul is testimony to how to witness in a post-Christian environment.

The following perspectives are evident from this passage:

- Paul was a strategist in selecting the larger cities, centres on trade routes, sea ports and places where there was much traffic. He chose these centres because the proclaimed message could have a far-reaching impact on people's lives (Green 2002:657).

The reason for the invitation to the Areopagus was Paul's message about Jesus Christ and His resurrection. Paul had disputes $(\delta 1 \varepsilon \lambda \varepsilon \gamma \varepsilon \tau 0)$ with all the people who met him in the synagogue because of the idolatry he saw in Athens. It was then that Paul started debating or arguing with people (Manser 2010:1953). Louw and Nida (1993:389) put this word $\delta 1 \varepsilon \lambda \varepsilon \gamma \varepsilon \tau \mathrm{o}$ in the subdomain of communication and more specifically in the subdomain of the various language levels of making a speech. This word can convey the following aspects, namely, to speak in a formal setting where language must be used (to make a speech) and also to argue or quarrel about differences. Bromiley (1985:155) indicates that this verb can also denote negotiation. The word 'dialogue' is evident in this Greek concept. In a city with different cultures and various idols Paul made use of dialogue in an attempt to converse with people who didn't understand the reality of idolatry. In Athens, a city where many different cultures met, Paul didn't hesitate to argue in a logical manner about the truth.

- Manser (2010:1953) made a very significant comment by indicating that Paul entered into conversations with people in the places where they were used to meeting. He met people in synagogues, in the marketplace and on the street. He was there. It could also be said that Paul didn't speak from outside or from above. He entered people's religious space to testify to the message of Christ. From the perspective of liturgical formation it is essential to note that believers meet one another where people are. Larkin (2006:252) underlines the imperative that people from different cultures should speak to each other with an attitude of integrity. 
- Paul walked around in Athens and observed. This literally means that he looked at all things again and again and he examined them carefully while he was walking (Larkin 2006:255).

- The point of contact on the Areopagus was 'what the people worship as something unknown' (Larkin 2006:256). The concept for worship is the word $\varepsilon v \sigma \varepsilon \beta \varepsilon 1 \tau \varepsilon$ Louw and Nida (1993:540) put this concept in the subdomain of worship and reverence. Therefore the expression denotes all things that are included in worship. Behind this concept lies the attitude of allegiance to a deity. Paul is concerned about the worship of this unknown God because of a lack of knowledge. Larkin (2006:546) describes the attempt to worship an impersonal deity as self-confessed ignorance, because the people in Athens didn't understand the true nature of worship.

- Paul's message was the message about the one true God as Creator, Ruler and Redeemer of all. It is this very fact that makes worship sensible (Larkin 2006:256). In Acts 17:25 it is revealed that God is not served $(\theta \varepsilon \rho \alpha \pi \varepsilon v \omega)$ by human hands, as if He needed anything (Larkin 2006:547). The concept of $\theta \varepsilon \rho \alpha \pi \varepsilon v \omega$ in this context denotes something that is normal in a cultic environment, namely the bringing of sacrificial fruits and of a cultic action (Larkin 2006:257).

- In this city where different cultures met, Paul made it clear that God does not dwell in houses made by human hands. It is striking that Paul wasn't using words and concepts that his audience was unfamiliar with; he started at the point where his audience was. Paul took the basic presuppositions of Christian teaching and formed or recast them into the language available to his hearers. This formation of Paul's preaching was an attempt to translate the story of Christ into the propositions of Athens (Blount \& Tubbs-Tisdale 2001:33).

- In this passage it is evident to note that preaching (Acts

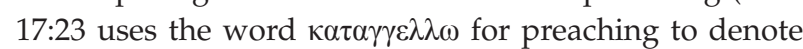
preaching as advocating or to make something known), for example, may require translations within different contexts that invite outsiders - even hostile outsiders - to hear more. Where different cultures with different customs of worship meet each other, it will be suitable to use the method of advocating the true message. This is possible only if believers are willing to meet other cultures where they are, on the street, in their places of worship and in the market place.

\section{Normative perspectives}

The following perspectives can be drawn from the exposition above:

- Participants in the liturgy of life should be present in this world. Outreach to society instead of withdrawal is needed.

- Churches should use opportunities to engage in dialogue with different cultures to identify the good things in each culture, but also to counter aspects in a culture that are not good.
- In the dialogue with other cultures a translation of the Gospel and principles of the Word of God should be included so that other cultures can understand the message of the Word. Cultures meet each other at the intersection of the Gospel regarding the resurrected Christ.

- When cultures meet one another, there is always the possibility of their going down a blind alley. The blind alley has to do with the hardened hearts of people. Although it can happen, dialogue between people of different cultures with the purpose of persuading is important. Persuasion is different from manipulation.

\section{Hermeneutical guidelines}

The hermeneutically interactive element evident in the following paragraphs is to bring the normative perspectives of this research into play with its descriptive and empirical findings. In the following discussion the authors provide the codes from the normative perspectives: this is followed by the correlating the empirical findings and indicators from the descriptive research. The contour lines that correlated with the interpretative perspectives in this research are also provided.

\section{Indicators and contour lines flowing from the descriptive and interpretative findings of this research}

\section{Formation through participation}

Continuous liturgical formation should involve liturgical activities because by participating in liturgical activities the mind, emotions and body of members as the Body of Christ will work together as a holistic entity.

\section{Formation through interaction}

Continuous formation takes place interactively with other cultures and liturgies through processes such as imitation, emotional attunement and interpersonal attachments.

\section{Formation through balance between action and knowing, tradition and enculturation}

In continuous liturgical formation, openness to differences may play a role in, for example, the expression of joy and sorrow and bodily movements during liturgical participation. The changes in liturgical formation are a balance between continuous preservation of the integrity of one's own liturgy and allowing for growth through social cognition, and between tradition and enculturation.

\section{Interpretative perspectives on social cognition from the viewpoint of social psychology}

\section{Cognition as a process through which people try to make} sense of other people

People's emotional experiences are influenced not only by their concrete situation, but also by their cognitive observation, appraisal or interpretation of that particular situation. 


\section{Cognitive distortions endangering perspective-making}

The danger also exists that one's observation of other people could be wrong. In the formation of liturgy it will become inevitable from a South African perspective that different cultures adopt new perspectives and learn to view liturgical formation from the viewpoint of other cultures.

\section{Codes from normative perspectives, correlations with empirical findings, descriptive indicators and contour lines according to interpretative perspectives}

- A presence in society is needed for continuous liturgical formation through cognition (code 1: presence). This is correlating with empirical findings 'in order to address the issue of (continuous) liturgical formation it is also inevitable that people from different cultures are exposed to each other' and also with 'worship services should make sense to participants in order to participate in daily life'. The above findings are correlating with the descriptive indicator 'formation through participation' and also with the contour line 'cognition as process in which people trying to make sense of other people'.

- Dialogue with cultures and their styles of worship is indispensable to distinguish the essence of continuous liturgical formation through cognition (code 2: dialogue). This is correlating with empirical findings 'the attitude of openness to learn from other cultures and also from their customs is enriching. It is a case of 'you are welcome here' and also 'feel welcome here' and 'in liturgical formation and especially where cultures are encountering it is obvious to utilise a common language and also to make room for other languages'. The findings are correlating with the descriptive indicator 'formation through participation' and also with the contour lines of 'cognition as process in which people trying to make sense of other people' and 'cognitive distortions endangered perspective-making'.

- The Gospel and the resulting liturgical principles should be translated during the encounters between cultures in responsible continuous liturgical formation through cognition (code 3: translation). This is correlating with the following empirical findings, namely:

- Before implementation of liturgical formation in a multi-cultural environment it is pivotal to comprehend the deepest need and also reason for it. When cultures are meeting each other it is imperative to be true to liturgical principles without ignoring the ability to adapt to new situations. The correct and responsible cognition of cultures and people are needed and this fact requires suitable study.

- Liturgy from the viewpoint of the liturgist and also from the side of people who are communicating aspects of liturgy during the worship service should be well prepared in order to help people make sense of it. Liturgical formation is asking for thorough consideration and for good preparation. People are also forming a cognition during the worship service.

- Everybody should realise the huge difference between principles and customs. The cultural heritage of drums, bells and cushion- hitting is clearly strange to other cultures, but it is not necessarily wrong. It became clear that customs and music are contributing towards a dedicated manner in which people feel they are meeting God and each other. Music styles and also music instruments could also be functional in order to promote liturgical formation

- Powerful and contextualised preaching of the Word of God contributes to a good assimilation of cultures. It prevents people from doing their own thing in a selfish manner, the value of rituals and symbols could never be underestimated when cultures are coming together. Rituals and symbols contribute to continuous liturgical formation.

- Bodily expression is functional for certain people. Participants in liturgy should feel free to express themselves in a way they are feeling comfortable with.

The above mentioned findings are correlating with the descriptive indicator, namely: 'formation through interaction' and 'formation through balance between action and knowing, tradition and enculturation'. The contours lines of 'cognition as process in which people trying to make sense of other people' and also 'cognitive distortions endangered perspectivemaking' are also correlating with the above findings.

- Dealing with the hardened hearts of people demands us to exert cognitive influence over others in order to promote continuous liturgical formation through cognition (code 4: cognitive influence). This is correlating with the following empirical findings, namely:

- Culture is playing a very crucial role in people's lives. Liturgists are responsible to help participants to make liturgy their own. Culture has the function to dress liturgy" The local congregation have a critical openness towards other liturgies. It is essential for them to listen and hear what other cultures do. In order to correct distortions in cognitions the role of good communication could never be underestimated.

- When cultures are coming together enrichment instead of attempts to conquer the other culture in order to form another culture should be evident.

- Participation in liturgy is helpful in people's understanding of the value of liturgy and worship services.

The descriptive indicator 'Formation through balance between action and knowing, tradition and enculturation.' and the contour lines of 'cognition as process in which people trying to make sense of other people' and 'cognitive distortions endangered perspective-making' are also correlating with the above findings.

\section{Conclusion}

The main research question for this investigation was: How does social cognition influence the process of liturgical formation? It is evident that social cognition plays a significant role in continuous liturgical formation, from both a normative viewpoint and the empirical findings. 
Thorough examination of the concepts of presence, dialogue, translation and cognitive influence is indispensable to the promotion of continuous liturgical formation through social cognition. Therefore there should be a strong emphasis on the liturgical principles handed down through the ages and a strong vision for the contemporary world. The role of liturgy and liturgical formation in a changing world with changing contexts that influence people's cognition require that even liturgy cannot function unchanged.

\section{Acknowledgements Competing interests}

The authors declare that they have no financial or personal relationships which may have inappropriately influenced them in writing this article.

\section{Authors' contributions}

B.J.d.K. and F.P.K. made equal contributions to this article. B.J.d.K. did research on the descriptive analysis, while F.P.K. did research on the normative section of this article. The section on the empirical work was also part of the collaboration of both authors.

\section{References}

Anderson, E.B., 1997, 'Liturgical catechesis: Congregational practice as formation' Religious Education 92(3), 349-362 (Summer).

Barker, R. \& Angepoulo, G., 2010, Integrated organisational communication, Juta, Cape Town.

Barnard, M. \& Vos, C.J.A., 2001, 'n Besinning oor die liturgie. Teorievorming, ondersoek en praktykvorming', Practical Theology in South Africa 16(2), 17-33.

Baron, R.A. \& Byrne, D., 1994, Social psychology, Allyn \& Bycan, Massachttetts.

Best, H.M., 2003, Unceasing worship. Biblical perspectives on worship and the arts, Intervarsity Press, IL London..

Blount, B.K. \& Tubbs-Tisdale, L., 2001, Making room at the table. An invitation to cultural worship, Westminster John Knox Press, Kentucky.

Bromiley, G.W., 1985, 'Dialegomai', in Theological dictionary of the New Testament pp. 422-423, Eerdmans, Grand Rapids, MI.

Burton-Edwards, T.W., 2013, 'Perspectives and limitations of current theories in neuroscience and cosmology in describing "full, conscious and actual participation in liturgical celebrations"', Liturgy 28(4), 41-59. http://dx.doi.org/10.1080/04580 $63 X .2013 .803852$
Clasen, F., 2008, 'Liturgy on the edge of change', Practical Theology in South Africa 23(1), 36-55.

Conder, T., 2006, The Church in transition, the journey of existing Churches into the emerging culture, Zondervan, Grand Rapids.

De Klerk, B.J., 2007, 'Liturgy and evangelism with special reference to the blessing', Practical Theology in South Africa 22(2), 20-40.

De Klerk, B.J., 2014, Liturgical involvement in society, Potchefstroom Theological Publications, Potchefstroom.

De Vos, A.S., Strydom, H., Fouchè, C.B. \& Delport, C.S.L., 2011, Research at grass roots, 4th edn., Van Schaik Publishers, Pretoria.

Eysenck, M.W. \& Keane, M.T., 2010, Cognitive psychology, Psychology Press, New York.

Fiske, S.T., 2004, Social beings: A core motives approach to social psychology, Wiley, Princeton, NJ.

Fowler, J., 1991, Weaving the new creation, Harper Collins, New York.

Gallet, J., 2000, 'Bodily-based imagination and the liturgical formation of children', Liturgical Ministry 9, 113-126 (Summer).

Geldhof, J., Larson-Miller, L. \& Stuflesser, M., 2014, 'Liturgical formation: Traditional task and new challenge', Newsletter of Societas Liturgica 39 (2014), 4-10.

Green, M., 2002, 'Good news from the first Christians', in D. Alexander \& P. Alexander eds., The lion handbook to the Bible, pp. 655-656, Lion Hudson, Oxford.

Heitink, G., 2007, Een Kerk met Karakter. Tijd voor Heroriëntasie, Kok, Kampen.

Immink, F.G., 2014, The touch of the sacred. The practice, theology and tradition of Christian worship, Eerdmans, Michigan.

Larkin, W.J., 2006, 'Acts', in W.J. Larkin, A.A. Trites \& P.W. Comfort (eds.), Cornerstone Biblical commentary, pp. 17-400, Tyndale, Illinois.

Louw, D. \& Edwards, D., 1998, Psychology. Introduction for students in South Africa, Heinemann, Sandton.

Louw, D. \& Louw, A., 2007, Die Ontwikkeling van die Kind en die Adolossent. $A B C$ Drukkers, Bloemfontein.

Louw, J.P. \& Nida, E.A., 1993, Greek English lexicon of the New Testament (I), United Bible Studies, New York.

Manser, M.H., 2010, The New Matthew Henry commentary, Zondervan, Michigan.

Moeller, P.A., 1998, Exploring worship anew, Chalice Press, Leicester.

Moynagh, M., 2012, Church for every context, Phillip Harold, London.

Osmer, R., 2008, Practical theology: An introduction, Eerdmans, Grand Rapids, MI.

Ostdiek, G., 1986, Catechesis for liturgy, Pastoral Press, Washington, DC.

Schwartz, L. \& De La Rey, C., 2004, Introduction to psychology, Oxford University Press, Oxford

Smith, J.K.A., 2009, Desiring the kingdom: Worship, worldview and cultural formation, M.I. Baker Academic, Grand Rapids, MI.

Strawn, B.D. \& Brown, W.S., 2013, 'Liturgical animals: What psychology and neuroscience tell us about formation and worship', Liturgy 28(4), 3-14. http:// dx.doi.org/10.1080/0458063X.2013.803838

Weiten, W. \& Weiten, S., 1992, Psychology: Themes and variations, Brooks, Belmont Westerhoff, J., 1987, 'Liturgy and catechetics', Worship 61, 510-516.

Wood, S.E. \& Wood, E.G., 1999, The world of psychology, Allyn \& Bacon, London.

Woolfolk, A., 2007, Educational psychology, Pearston, Boston. 